Journal of Humanities, Social and Management Sciences (JHSMS) eISSN: 2788-4791 (Online) https://doi.org/10.47264/idea.jhsms/2.1.1 Vol. 2, No. 1 (January-June 2021), 1-9

\title{
Unilateral vs. multilateral approaches in US foreign policy: A case study of Iraq and Afghanistan war
}

\author{
Amna Mahmood* | Tatheer Zehra Sherazi | Wajeeh Shahrukh \\ Department of Politics \& International Relations, International Islamic University, Islamabad, Pakistan. \\ * Corresponding Author Emails: amna.mahmood@iiu.edu.pk| scholar2020@gmail.com
}

Published: August 1, 2021

\begin{abstract}
During US war on terror in Iraq and Afghanistan, the Bush administration vindicated its preemptive military strikes against Iraq and Afghanistan on the grounds of national security. The strike was carried out under the Bush administration's National Security Strategy which asserts the right of the U.S to take unilateral military action against rogue states and terrorist organizations in order to prevent or to reduce an assumed attack by such groups or organizations against the United States. However, the action by the administration has been widely criticized as not being in conformity with international law, and United Nations' Security Council resolutions. It has been investigated in this research paper that the hidden motive behind the attacks on these two countries was not merely the elimination of the terrorist groups and to stop their activities and to destroy the weapons of mass destruction but to capture the oil, gas, and other natural resources in order to sustain the fastest growing economy of the US and western countries. The present study will present a comparative analysis of the two approaches; unilateral and multilateral which were incorporated in U.S foreign policy with the special reference of Iraq and Afghanistan war.
\end{abstract}

Keywords: US War on Terror, US-Iraq Relations, US-Afghan Relations, Afghan War, Iraq War, Post 9/11 US Policy.

\section{How to Cite:}

Mahmood, A., Sherazi, T. Z., \& Shahrukh, W. (2021). Unilateral vs. multilateral approaches in US foreign policy: A case study of Iraq and Afghanistan war. Journal of Humanities, Social and Management Sciences (JHSMS), 2(1), 1-9. https://doi.org/10.47264/idea.jhsms/2.1.1

\section{Publisher's Note:}

IDEA PUBLISHERS (IDEA Journals Group) stands neutral regarding jurisdictional claims in the published maps and institutional affiliations.

\section{Copyright:}

(C) 2021 The Author(s), published by IDEA PUBLISHERS (IDEA Journals Group)

This is an Open Access article published under the Creative Commons Attribution-Non Commercial 4.0 International License (http://creativecommons.org/licenses/by-nc/4.0/) 


\section{Introduction}

Unilateralism has had a long history in the US foreign policy. In his famous and influential farewell address, George Washington warned that the United States should steer clear of permanent alliances with any portion of the foreign world. Many years later, this approach was labelled (by its opponents) as isolationism, but some historians of U.S. Diplomacy have long argued that isolationism is a misnomer, and that U.S. foreign policy, beginning with Washington, has traditionally been driven by unilateralism (Malone \& Khong, 2003). It was the period after the Second World War when the shades of multilateralism emerged in the U.S foreign policy and the U.S became engaged in a flurry of multilateral engagements such as U.S involvement in the United Nations (UN), World Trade Organization (WTO) and International Monetary Fund (IMF) (Davidovic, 2002). Throughout the 1990's the United States relied mostly on a foreign policy based on multilateral efforts. However, the signs of unilateralism in U.S foreign policy began to appear in 2002 with the planning of the Iraq War.

The Americans based their case for military action on the alleged existence of Iraqi weapons of mass destruction (WMD) as well as Saddam Hussein's alleged links with Al Qaeda terrorists. Pre-emptive strikes as a part of strategy can be found throughout military history. The declaration of pre-emption as a US strategy came when it was embodied in the United States National Security Strategy (NSS) that, "We will not hesitate to act alone, if necessary, to exercise our right of self-defence by acting pre-emptively against such terrorists, to prevent them from doing harm against our people and our country" (Bush, 2002). Unilateralism adopted by U.S have to face a resistance in the form of the veto of resolution 1441 on Iraq by Russia and France, which sent a serious message to the US. Majority of the European nations wanted the disarming of Iraq and were against war. In case of U.S invasion of Afghanistan the war was justified on the pretext of the 9\11 terrorist attacks on world trade centre and pentagon in America (Kissenger, 2001). The US war against Afghanistan was justified under the article 51 of the United Nations charter which allows the use of force in self-defence against an aggressor. Apart from this NATO in the spirit of its article 5 considered the attack collectively and came took an initiative to fight against the culprits collectively.

\section{Theoretical foundations}

The term "Multilateralism" in the context of foreign policy refers to a state's desire and quest to pursue its interests and objectives through building cooperation and friendly relations with other states. Oppositely, if a state adopts a unilateral approach in its policy formulation to pursue its national interests, then it is supposed to be supported by its own sources and forces, irrespective of whether these are based on a strong economy, a high technological standard or on strong military capacities (Calkins, 2000). The comparative approach is not only considered as the best tool to present the broader and wider spectrum of different arguments but it is equally useful to locate the structural weaknesses.

\subsection{Unilateralism}

The term "Unilateralism" refers to a set of doctrines or an agenda that supports one-sided action, such action may be proved harmful for other states or political actors. The founders of this approach view the world as unipolar where only one super power exists and that is U.S. According to this approach, unilateral action occurs when one country does something on its 
own, without coordinating with other countries. In politics, the term is often used to refer to country's actions which are taken on their own without the assistance or approval of other countries taking action one sided. In other words, it is a term which is used when discussing foreign policy in general and the foreign policy of United States in particular. Unilateralism simply means acting alone mostly without the consultation or support of other nation-states. Under unilateralism a state is able to act independently and actions can be accomplished more quickly because wide-spread debate over policies is minimized, and other nations do not have veto power over a country's policies. Independent action also allows a central authority to develop during a conflict, and states do not have the difficulty connected with the divided authority resulting from multilateralism (Malone \& Khong, 2003).

Unilateralism has had a long history in the United States. In his famous and influential Farewell Address George Washington warned that the United States should steer clear of permanent alliances with any portion of the foreign world. The U.S foreign policy beginning with Washington has traditionally been driven by unilateralism. Unilateralism in recent times came to the vanguard with the Iraq War. While over 30 countries have supported the U.S. policy some previous American allies such as France, Germany and Turkey are not participating. Many opponents of the war have argued that the United States is "going in alone" in Iraq without the support of multilateral institutions (Chossudovsky, 2010).

\subsection{Multilateralism}

Multilateralism is a diplomatic term that refers to cooperation among several nations. The founders of this approach argue that world order is not uni-polar; rather it is multi-polar or unimulti-polar in which many friends or rival states exist that cooperate with each other or go against each other to secure their own interests. In the second sphere that is uni-multipolar, the world is divided into lines. In one line the major and super power, U.S lives and in the second line, medium and major powers reside but their influence across the whole world is limited as compared to U.S (Rabbani \& Shahzad, 2007). It is a sort of cooperation among three or more Nations in order to solve some common foreign policy problem. It refers to a state's quest to affirm its interests and goals through cooperation and coalitions with other states.

Prior to the W.W.I American foreign policy was unilateral (Nye, 2002). Even American involvement in World War I was a unilateral venture. Multilateralism is largely a post-World War II element of U.S. foreign policy. US became involved in a flood of multilateral diplomatic, economic, and humanitarian activities. The U.S. joined the war's victors at the creation of World Bank and International Monetary Fund in 1944, United Nations in 1945, World Health Organization in 1948, North Atlantic Treaty Organization in 1949. As multilateralism entails a dual commitment to both invest in and comply with the rules of an institutionalized international order. The adoption of multilateral approach in U.S foreign policy could be able to lessen the grievances and resentments of other states towards U.S.

\section{US interests in Afghanistan}

The U.S led coalition war on Afghanistan is part of a profit driven agenda, it is a war of economic conquest and pillage a war to capture the resources (Nichol, 2011). The legal argument which was put forward by Washington and North Atlantic Treaty Organization to invade and occupy Afghanistan was under the doctrine of collective security it was that the 
Unilateral vs. multilateral approaches in US foreign policy: A case study of Iraq \& Afghanistan

September 11, 2001 attacks constituted an undeclared armed attack from abroad by an unnamed foreign power.

\subsection{To secure the region's oil and gas}

Oil played a big role in precipitating the US bombing of Afghanistan in October 2001 in the name to kill Osama bin Laden and his Al Qaeda network. Afghanistan territory itself has very little oil and gas of its own but its real importance lies in its geographical location as it is the gateway to Central Asia. America never had been unaware of this fact and its tacit support to the Taliban in 1996-7 was motivated by the need for a strong government in Afghanistan that would pave the way for US-sponsored pipelines from Central Asia. Continued transportation through Russia would have prolonged that country's economic and political control over the region, while pipelines through Iran were also unacceptable, as they would have benefited a regime unfriendly to the U.S. A secure Afghanistan was considered the best option (Gupta, 2008). While Afghanistan is recognized as a strategic hub in Central Asia and that is considered as a transit country for oil and gas, bordering on the three CARs (Tajikistan, Turkmenistan, and Uzbekistan) China and Iran at the crossroads of pipeline routes and major oil and gas reserves, its huge mineral wealth as well as its untapped natural gas reserves allured the U.S and its allies to wage a war against Afghanistan (Gusev, 2012).

A remarkable opportunity was provided to the United States to extend its involvement in the Central Asia in the backdrop of the catastrophic attacks of September 11, 2001 in New York and Washington. Alleged terrorist mastermind, Osama bin Laden, was held responsible for the attacks, and the Taliban regime in Afghanistan was accused of providing him refuge. A ground invasion along with a massive bombing campaign was planned against Afghanistan, the aim of the war was to eliminate whatever remained of the Taliban and bin Laden's Al Qaeda network (Calkins, 2000). Three of the Central Asian Republics states Tajikistan, Turkmenistan, and Uzbekistan are sharing borders with Afghanistan, which made them critically important to an effective prosecution of the American campaign. Uzbekistan and Tajikistan provided military bases to the Americans in exchange they were given generous financial assistance, while over flight rights to US warplanes were provided by Turkmenistan. Subsequently, the US managed to construct a base in Kyrgyzstan as well, even though it does not share a border with Afghanistan.

It is in the interest of US to establish a multilateral and effective system in the Caspian and Central Asian regions in order to supply oil and gas to Europe and other markets in order to reduce the dependence of European and Central Asian countries on the Russian energy monopoly. it is also important for Washington from the standpoint of geo-economics that it should try to redirect Central Asian oil from China to a market controlled by the stock exchanges in New York, London, Tokyo and Singapore and find ways to transport Caspian Sea resources without going through Iranian territory, irrespective of the fact that the route with access to the Persian Gulf is more cost-effective. That was the reason for the Baku-TbilisiCeyhan oil pipeline, which transports Kazakh oil (Martin, 2001).Currently America is enjoying its military presence in Central Asia to what an extent that it was unimaginable prior to 9/11; it is now considered as security manager of the region, which is a much alarming sign to its major rivals: Russia, China, and Iran. All three of them already feel sufficiently encircled by American military involvement in other areas (Russia by NATO's eastward expansion, China by the American support to Taiwan, and Iran by the bases in the Persian Gulf). 


\subsection{Containing Russia, China, and Iran}

Another major objective of U.S in Afghanistan and Central Asia is to decrease the influence of important regional players such as Russia, China, and Iran. Russia is likely to lose the most from a long-term U.S presence in Central Asia. Ever since the CARs got independence after the disintegration of former U.S.S.R, Russia has been enjoying the status of the most influential external player in the region, both through its monopoly over energy transportation as well as by virtue of its position as the guardian of the Republics' territorial integrity. Most of the people in Russia's official circles are of the view that Russia is enjoying a distinct set of economic and security interests in the region, which other powers should be indebted to respect. It is a common fear among Russian foreign policy pundits and security specialists that any increased U.S involvement in the region will be the preface to an ultimate military presence in the region. American troops are now present in three Central Asian states and they are not showing any signs of an impending withdrawal so it appears that those fears are by no means unfounded.

The military presence of the U.S in Central Asia is providing an opportunity to the Americans to monitor the activities of China and Russia in the region and to maintain a military foothold there so they keep trying to recover their bases in Uzbekistan and increase their usage of Kazakhstan's airfield network to support military operations by coalition forces in Afghanistan. The basic missions that Washington will try to find to achieve in the military and political sphere include to increase its military presence in Central Asia and to attain the capability for possibly to intervene in Iran's affairs, to contain China militarily, and to put pressure on Russia and in the future on India as well and to ensure that America is competent of reacting quickly to actions by international terrorists and Islamic radicals in Afghanistan, Pakistan and other South Asian countries and to a lesser extent in controlling the drug trafficking (Rabbani \& Shahzad, 2007).

\subsection{US invasion of Afghanistan 2001 (Operation Enduring Freedom)}

Following the $11^{\text {th }}$ September, 2001 attacks in US, a resolution was issued by the UN known as Security Council Resolution 1368 (2001) on $12^{\text {th }}$ September, the resolution is widely interpreted as a UN authorization for military action in response to the attacks. On 20 September, the War on Terror was announced by U.S and it was demanded that the Taliban should deliver the leaders of al-Qaeda and close all terrorist training camps within its borders. On 7 October 2001 the US began Operation Enduring Freedom as an international armed response. The Northern Alliance was given support through special operation forces that targeted positions through air strikes and missiles launches from US and British ships and submarines. The war was marked as the beginning of the United States war on terrorism campaign. Nonetheless, the aim of the war was to oust the Taliban and find al-Qaeda leader Osama bin laden, to eliminate the terrorism, to destroy terrorist training camps and to deter state sponsored terrorism. The U.S military name of the war was operation enduring freedom (Annan, 2004).

\section{US interests in Iraq}

Some months before the disintegration of the Soviet Union, Iraq invaded Kuwait in august 1990 as a consequence US-led coalition had declared war on Iraq. Iraq was swiftly subdued, but its brutal ruler, Saddam Hussein, was allowed to remain in charge. The rationale behind 
this decision was that during the war, the US had successfully set up military bases in Saudi Arabia, Kuwait, Qatar, and Bahrain, and it needed to keep alive the spectre of a psychotic Saddam Hussein breathing down the necks of his nervous neighbours just to justify a prolonged military presence in the oil-rich and strategically-located Persian Gulf. It has been a regular practice of all the empires to set the bases, and the US has been no different in this regard. After every major war in which America has been involved, it has left behind bases to ensure its continued involvement and intervention in the years to come. The Second World War, the Korean War, and the Vietnam War provide more than enough evidence not only of America's tendency for setting up overseas bases but also of its utmost unwillingness to give up them, even when the supposed threat has become non-existent.

\subsection{Bush Administration's rationale to attack Iraq}

The first difficulty the Bush administration had to clear was to legitimize war on a state that did not make threats to the US. The issue of WMDs was hit upon as a way to turn the war on terrorism against Iraq to do so, Bush had to claim that Saddam Hussein was linked to al-Qaida and was actively developing weapons of mass destruction which he might turn over to terrorists or use on their behalf, and therefore that Iraq represented a looming threat to the US. The bush administration supposedly provided the following rationale for its attack on Iraq. The first reason given by America was the elimination of the weapons of mass destruction, the second logic which the bush administration putted forward to justify its attack on Iraq was the liberation of the Iraqi people from the brutal regime of the Saddam Husain and the establishment of the liberal democracy, and the third reason was to facilitate the America on its international war on terrorism. The reason which was mostly given by the bush administration for going to war with Iraq is to reduce the risk of a WMD attack on the United States. Prior to the 2003 attack on Iraq the governments of the United States and the United Kingdom claimed that Iraq has alleged weapons of mass destruction (WMD), which posed a great threat to their security and that of their coalition / regional allies.

\subsection{Bush Doctrine and the Iraq War}

The Bush doctrine has its origins in the September 11, 2001 attacks on New York, Washington D.C. and Pennsylvania. The most important part of the doctrine is that unilateral pre-emptive force may be used even in instances where an attack by an enemy has neither taken place nor is imminent. In response to the security threats, President George W. Bush announced a new National Security Policy of the United States on 17 September 2002, which was a part of the Bush Doctrine, or the doctrine of pre-emption, whereby the United States would not wait until after an attack to respond but would use military force to eliminate potential threats before they could be put in motion. There are three paramount objectives assumed in the Bush doctrine:

- First was about the removal of governments repugnant to the US.

- Second was about the use of pre-emption against such governments, terrorists and weapons of mass destruction programs of the rogue regimes.

- Third was about that when necessary, US will take unilateral action where allies are not forthcoming (Skidmore, 2005).

When President Bush announced this policy, actually he was laying the groundwork for war with Iraq and this policy was behind the decision to invade Iraq in 2003. In the aftermath of 
9/11, the new president got the opportunity to attack Iraq. But the decision to attack Iraq was lacking direct provocation, the rationale and justifications for war conflicted with Just War principles. The new Bush doctrine of pre-emptive war was encountered with immediate international opposition, but as there was a perceived threat of weapons of mass destruction so a coalition of the willing led by the U.S was assembled to invade Iraq.

The other considerable happening during this conflict were the world-wide mass demonstrations, and some 500 pro-peace events in the US itself, calling President Bush's decision to go to war, as malfeasance and asking for this war to be prevented and prohibited. This implied a worldwide abhorrence towards the war. Pre-emption and just war require the undaunted support of allies in war if not of the whole world community. In the most idealistic sense pre-emption requires that the promoters of war must present evidence that the adversary is illogical, unreasonable or at least incompetent of making sound decisions under the situation. These proofs provide the bases of gaining general support for the pre-emptive action. The case of US-Iraq conflict of 2002-3, the case was found weak on both these counts. Irrationality of the Iraqi regime could not be recognized and the support of staunch allies of the past like France and Germany was lacking. The confidence and support of allies is one of the basic proofs of their faith in the success of the journey and the chances of an inclusive pre-emptive action. Bush's Iraq dialogue failed to persuade those who were not already true believers in the need to invade Iraq and many of the US's traditional allies were deeply annoyed by Bush's pride and were distanced and were not convinced by his rhetoric.

\subsection{UN Charter and US Pre-Emptive war against Iraq}

The pre-emptive strikes by individual nations or the groups of nations without the approval of the UN Security Council are illegal according to the United Nations charter. Although the UN Charter looks for the refusal of the use of force by states against their adversaries, it does recognize the right of a nation to use force for the purpose of self-defence (Article 51). But this right of self-defence is legitimate only when an armed attack has already occurred on a nation and the Security Council has not been able to take the necessary measures to prevent the attack. Thus, Article 51 prohibits the pre-emptive use of force by individual states or groupings of states and holds such use of force entirely to the Security Council. Measures in self-defence, in this context, are legitimate only after an armed attack has already occurred. But in the case of Iraq war the American attack on Iraq in 2003 appeared to be in violation of the right to selfdefence because Iraq did not attack the US. Since there was no proof that an attack by Iraq on the US was imminent, an attack in self-defence amounted to usurpation of the UN Security Council's role. Although the US accused the UN Security Council of failing to act against Iraq, the Bush administration failed to show how Iraq constituted an immediate threat to the security of the US (Malik, 2004).

\subsubsection{UNSC Resolution 678}

In the backdrop of Iraq's invasion of Kuwait in 1989, UNSCR 678 was passed by the Security Council, which permitted legal use of force in the first Gulf War.

\subsubsection{UNSC Resolution 687}

The first gulf war ended in 1991 resulting in a cease-fire, and resolution 687 was passed stating 
that UN weapons inspectors must be allowed free reign in Iraq to ensure WMDs aren't developed. If this condition was not met, the cease-fire would be broken and the rules of resolution 678 allowing the use of force would be reinstated.

\subsubsection{UNSC Resolution 1441}

In January 2002, Iraq, Iran, and North Korea were identified as an" axis of evil" by President Bush. Bush said that the world's most dangerous regimes with the world's most destructive weapons will not be permitted by the United States of America to threaten its security. On September 12, 2002, a sharp debate occurred within the Bush administration over what to do about Iraq, after that the president addressed the United Nations. He warned that disarming Iraq of its weapons of mass destruction (banned by the U.N. after the 1991 Gulf War) will be enforced by the U.N. or if necessary, it will be done by the United States acting unilaterally in self-defence. Finally, the famous resolution 1441 was passed by the Security Council in 2002 stating that Iraq will face 'serious consequences' if they don't allow weapons inspections. But this was not seen as the green light for war, as acknowledged by all countries including the US and Britain a further resolution expressly giving permission for war was necessary.

After this, Hans Blix, the UN Chief Weapons Inspector, said he had checked the majority of sites with free access, found no evidence of WMDs, and only needed a couple more months to finish their job. Prior to the attack, the United Nations Monitoring, Verification and Inspection Commission (UNMOVIC) found no evidence of WMD, but could not yet verify the accuracy of Iraq's declarations regarding what weapons it possessed, as their work was still unfinished. The United States nevertheless in March 2003 invaded Iraq without a new resolution with a "coalition of the willing" to remove Iraqi weapons of mass destruction, stating that the weapons inspectors had not been allowed free access, therefore breaking resolution 687, and permitting the use of force under resolution 678 as per the first Gulf War (Lieber, 2002). The coalition included Great Britain and 29 other nations. It did not include any Arab states or some NATO members, including Canada, France, Germany, Belgium, and Norway. On March 20, 2003, the coalition forces, consisting mainly of U.S. and British troops, invaded Iraq. The war lasted several weeks and toppled the Iraqi government of Saddam Hussein.

\section{Conclusion}

The UN Charter affords nations opportunities to defend themselves and to take unilateral action in self-defence under Article 51, but the Bush doctrine seeks to bypass this provision and respond to geopolitical threats from outside of the UN framework. In this, the doctrine raises US exceptionalism and unilateralism to unprecedented heights and in the process reinforces the interventionist, hegemonistic, and imperialistic tendencies of US power. In having attacked Iraq unilaterally, the USA has opened afresh the doors for future wars. When the Security Council adopted Resolution 1441, France, Russia, and China issued a declaration indicating that the resolution excluded the authorization of military force. Resolution 1441 authorized the Security Council to determine the future course of action against Iraq in case of its noncompliance with this resolution. It did not empower any country or group of countries to take unilateral action against Iraq in the event of the latter's violation of the resolution. The unilateral action initiated by the USA was thus clearly in absolute violation of Resolution 1441. The initial response of the United States to these attacks was the invasion of Afghanistan and the toppling of the Taliban regime. while the United States were legally permitted to attack 
Afghanistan under the self-defence provisions of the United Nations Charter, the US led invasion of Iraq was neither legal under the Charter nor under the pre-Charter customary law.

\section{References}

Annan. (2004, September 16). Iraq war was illegal and breached UN charter.The Guardian. https://www.theguardian.com/world/2004/sep/16/iraq.iraq

Bush, G. W. (2002). The national security strategy of the United States of America. The White House.

Calkins, A. M. (2000). Multilateralism in international conflict: Recipe for success or failure? Wake Forest University.

Chossudovsky, M. (2010, June 16). The war is worth waging: Afghanistan's vast reserves of minerals and natural gas. Global Research. http://www.globalresearch.ca/the-war-isworth-waging-afghanistan-s-vast-reserves-of-minerals-and-natural-gas/19769

Davidovic, S. (2002). American foreign policy between unilateralism and multilateralism. Rheinische Friedrich University.

Gupta, S. (2008). The doctrine of pre-emptive strike: Application and implications during the administration of president George W. Bush. International Political Science Review, 29(2), 181-196. https://doi.org/10.1177\%2F0192512107085611

Gusev, L. (2012, March 27). The US interests in Afghanistan and Central Asia. Russia and India Report. http://in.rbth.com/articles/2012/03/27/the_us_interests_in_afghanistan_and_central_ $\underline{\text { asia_ } 15276}$

Kissenger, H. (2001). Does America needs a foreign policy: Towards a diplomacy for the 21st century. New York.

Lieber, R. J. (Ed.). (2002). Eagle rules? foreign policy and American primacy in the twentyfirst century. Pearson College Division.

Malik, A. I. (2004). An evaluation of pre-emption in Iraq. Islamabad Policy Research Institute (IPRI) Papers, No. 8. https://ipripak.org/wp-content/uploads/2014/01/ipn8.pdf

Malone, D., \& Khong, Y. F. (2003). Unilateralism and US Foreign Policy: International Perspective. Lynne Rienner Publishers.

Martin, P. (2001, November 20). US planned war in Afghanistan long before September 11. World Socialist Website. https://www.wsws.org/en/articles/2001/11/afgh-n20.html

Nichol, J. (2011). Central Asia: Regional developments and implications for US interests. Current Politics and Economics of South, Southeastern and Central Asia , 183.

Nye, J. (2002). The new Rome meets the new Barbarians: How America should wield its power? The Economist, 362, 23-24.

Rabbani, G., \& Shahzad, A. (2007). Understanding International Relations. Lahore: Aemer Publications.

Skidmore, D. (2005). Understanding the unilateralist turn in US foreign policy. Foreign Policy Analysis, 1(2), 207-228. https://doi.org/10.1111/j.1743-8594.2005.00010.x 